\title{
Enjambment and End-stopping in the Magnum Opus of the Three Renowned poets: Chaucer, Gower, Langland
}

\author{
Amin Rastar \\ Student of PhD in English Literature at Faculty of Foreign Languages and Literature, Department of English Literature, \\ University of Tehran, Tehran, Iran
}

\begin{abstract}
Poetry, being one of the two main categories of literature in general, has recently been subject to subordinate attention in literatures in terms of form, especially the poetic part of medieval epoch. Alongside the structural and semantic aspects of poetry, there still remain some elements of this style not fully investigated and developed. Amongst such we can name end-stopping andenjambment, which are some categorical elements, most of the poets, either intentionally or ignorantly, have administered from the medieval era to the present time. In this paper, the existence of enjambment and end-stopping was investigated in three of most renowned poetic works of Middle-English era, including Chaucer's Canterbury Tales, Gower's Confessio Amantis, Langand's Piers the Plowman. By comparing the original text of the poems with the translated form of them, it was understood that the existence of end-stopping was more significant and the number of end-stopped lines were more than enjambed ones. It was then concluded that medieval poets, specially these three, used mostly a language simple in structure and easy to understand syntactically, free from the complexity that enjambment brings to the lines.
\end{abstract}

Keywords- Poetry, Enjambment, End-stopping, Chaucer, Langland, Gower.

\section{REVIEW OF LITERATURE}

Poetry, in general, has been a hot issue of discussion among specialists of this field since the time Aristotle's poetics was published up to the present time; however, searching into this great deal of literature, we rarely find ones which deal with formalistic elements of poetry, and in this case, enjambment and end-stopping.These two terms had been defined many times by different glossaries of literature and dictionaries, but a few academic researcheshave been done on them in poetry. Nevertheless, there are people who have focused their work on enjambment, end-stopping and their importance. Reuven Tsur, in many of his articles, like in The Performance of Enjambments: Perceived Effects and Experimental Manipulations ${ }^{l}$, investigated the role and performance of enjambment. He has examined the phonological and rhythmical influence that enjambment imparts onto the structure of the poem. Masahiro Hori, Tomoji Tobata, Gadahiro Kumamoto, Hiroyuki Ito, in their book Stylistic Studies of Literature, investigate the enjambment technic in Chaucer's poetry. Chaucer, in this work, is counted as one of the pioneers in using the technic of enjambment and has been greatly commended for this art. It is the proficiency of Chaucer that makes Brink to appreciate him, in his Language and Meter of Chaucer, in this way:

"No epic poet has availed himself of enjambment with greater felicity than Chaucer, none has by the most varied and yet measured use of this device... been more successful in producing a combination of movement and repose, variety and uniformity."

Alan T. Gaylord, has also dedicated a great deal of his work in Art of Chaucer's Verse to the use of this technic in Chaucer's works. Few works have been done on Langland and Gower stylistically and formalistically, amongst which, to no specific work we can refer.

End-stopping, whose nature is a bit clearer than enjambment, has also been subjected to little attention by critics, thus no specific work can be cited in this field.

\footnotetext{
${ }^{1}$ The electronic version can be found on http://www.psyartjournal.com/article/show/tsur
} 


\title{
II. INTRODUCTION
}

Enjambment and end-stopping, or in general line breaks, are the two fundamental elements making a poetry look different when compared to prose. Of the importance of enjambment, Brink says: "it is an indispensable device for the animation of poetical speech and the avoidance of monotony." In this paper we have tried to examine these two elements in three of the most known poems in medieval era of English poetry. Enjambment, as an art claimed by many critics such as Brink ${ }^{3}$, adds to the complexity of verse and its superficial lexical appearance. We assume that, as critics such as Gaylord, in his Art of Chaucer's Verse claim, poets of the Middle-English era were more concerned about their wordings and the whole structure of the verse rather the structure of exclusive lines; he of course exceptions Chaucer for some of his works such as the Legend of Good Women, in which enjambment, though being used, is not the most significant technic. Suppose that I utter the lines "I want to say goodbye to you/because I don't love you" in this way: "I list to fare thee well/Sith I love thee not" and "fare thee well, since I don't love thee/Is what I list to say." Amongst these two, it is evident that the latter is harder to understand; the second one, being enjambed, has totally changed, in fact, disordered the structure of the sentence. Therefore, we expect the number of enjambed lines to be less than end-stopped ones in these poetry, if, of course, any exist. To examine this, we first have to define the terms in order to be able to examine them in the texts. Although these two are of most basic technics used in poetry composition, scholars provide different definitions for them. For instance, Bernhard ten Brink, defines enjambment as "separation of even closely connected elements of a sentence by the conclusion of the metrical line"4 or as J. A Cudon notes, in his Dictionary of Literary Terms: "...running on of the sense beyond the second line of one couplet into the first line of the text."

Lexically, the term enjambment is derived from the French wordenjambement, from the verb enjamber which means to stride, step over, straddle, or stretch across according to Le Grand Robert dictionary. In French jambe means leg, and when the prefix en- is added to it, it becomes: to leg/step over.

Sharad Rajimwale, in his Dictionary of Literary Terms says of enjambment:

"In verse, when the sense is continued from one line to the next so that it appears unnatural to pause while reading the first line..."

B. Dupriez defines it as a sentence that "runs on from one line (of poetry) to the next, without there being a marked stop" 5 Both Britannica and Merriam Webster encyclopedias, alongside Cudon, Rajimwale, and Meyer ${ }^{6}$ (Michael C.; not to be mistaken with Meyer H. Abrams), defines enjambment as running on of "sense" only, whereas some other critics also bring grammatical structure into their definition. In fact, critics like Rajimwale and Cudon focus on the semantic aspect of a line, while critics such as Brink ${ }^{7}$, Dupriez ${ }^{8}$, Chris Baldick ${ }^{9}$, William Hint Thrall, ${ }^{10}$ James Shipley $^{11}$, and Martin Garey ${ }^{12}$, look at the syntactical sequence between lines and identify enjambment as the running on and continual of both "sense" and "grammatical structure" into the next line of the poem. Take this passage from James Shipley's Dictionary of World Literature into consideration:

"...the carrying of sense (grammatical forms) in a poem past the end of a line ..."

Amongst these, ten Brink's definition fits best our intention, since all other definitions are either too broad or general, or suffer a lack. In this paper, we base our discussion on Brink's definition.

There is also a debate on whether enjambment is the carrying of sense and structure from any single line to another or the first line of a couplet ${ }^{13}$ to the second one. On this, James Shipley says it is either "...past the end of a line" or "(in heroic couplet ${ }^{14}$ )

\author{
${ }^{2}$ Stylistic Studies of Literature \\ ${ }^{3}$ The Language and Meter of Chaucer \\ ${ }^{4}$ The Language and meter of Chaucer \\ ${ }^{5}$ A Dictionary of Literary Devices \\ ${ }^{6}$ Glossary of Literary Terms \\ ${ }^{7}$ The Language and meter of Chaucer \\ ${ }^{8} \mathrm{~A}$ Dictionary of Literary Devices \\ $9_{\text {in Oxford Concise Dictionary of Literary Terms }}$ \\ ${ }^{10}$ in a Handbook of Literature \\ ${ }^{11}$, in A Dictionary of World Literature \\ ${ }^{12}$, in Dictionary of Literary Terms \\ ${ }^{13}$ Two lines of verseusually rhymed. More often, part of a series of lines rhyming in pairs, in stanzas and poems of various \\ lengths (Shipley's Dictionary of World Literature) \\ ${ }^{14}$ The iambic pentameter in pairs of rhyming lines, continuous through a poem (Shipley's Dictionary of World Literature)
}


past the end of the couplet". William H. Thrall identifies enjambment as a phenomenon which "...continues from a verse or couplet on to the next verse or couplet..." According to J.A. Cuddon, enjambment is "...running on of the sense beyond the second line of one couplet into the first line of the text." And the last one but not least, Chris Baldick says "...from one verse line or couplet to the next without a punctuation pause."

In contrast, Meyer and Rajimwale assert that enjambment happens from one line to another and do not make any point about the occurrence of this technic in a couplet; however, we'd rather accept the former as it is more prevalent and is more referred to. Examples of enjambment in a couplet can be seen in Langland's Piers the Plowman:

[In a somer sesun, whon softe was the sonne,

I schop me into a shroud, as I a scheep were;]

[In habite as an hermite unholy of werkes

Wente I wyde in this world wondres to here;]

[Bote in a Mayes morwnynge on Malverne hulles

Me bifel a ferly, of fairie, me-thoughte.]

This device is also called run-on, as Abrams and many others say, and the enjambed lines, run-on lines.

This technic has mostly been used in the verse form "Blank Verse" which is metered but lack rhymes and rhyme scheme; however it appear in other forms too, such as "Closed Couplet ${ }^{15}$ " or "Heroic Couplet." ${ }^{16}$ It was commonly used by $16^{\text {th }}$ and $17^{\text {th }}$ century poets (in blank verse) and less frequently in $18^{\text {th }}$ century. Romantic poets revived its use (in closed couplet) which was a part of reaction against what they felt as restricting rules governing the composition of poetry, while enjambment would emancipate them from the closed-ness and restrictedness of end-stopped lines, which we later define ${ }^{17}$.

In general, we define enjambment as the continual or flow of sense or structure of a line or a couplet into the next line or couplet, the former being not paused by any terminal punctuation. Enjambed lines are deficient both in terms of structure and meaning that is they are neither complete grammatical clauses nor complete sentences semantically. Examples of such device are Keat's Endymion [oxford, meyer, J A cudon], Ralph Hodgson's Eve [rajim], William Wordsworth's There was a boy [Martin Garey] and many other.

Consider an example from Chaucer, who is, as Alan T. Gaylord, in his the Art of Chaucer's versequotes (form ten Brink), themaster of enjambment:

Whan that April with his showres soote

The droughte of March hath perced to the roote,

-from the General Prologue

Another example from John Gower's Confessio Amantis:

These olde worldes with the newe

Who that wol take in evidence,

-From book 5

As you may have understood, these linesare structurally and semantically related to each other,and as our definitions say, there is no punctuation pause at the end of the first line. This means they are enjambed.

The other phenomenon, which is exactly the opposite of enjambment, is called end-stopping and is defined as

“...end-stopped lines are those brought to a pause at which the end of a verse line coincides within the

completion of a sentence, clause or phrase, or other independent units of syntax; it gives lines an appearance of self-contained sense..."

- Oxford Dictionary of Literary Terms

"A line that has a natural pause at the end (period, semicolon, question mark, exclamation mark or comma)..."

\footnotetext{
${ }^{15}$ Pair of usu. rhymed units of lines whose sense does not extend beyond them; end-stopped couplet (Shipley's Dictionary of World Literature)

${ }^{16}$ Oxford Dictionary of Literary Terms

${ }^{17}$ According to J.A. Cudon's Dictionary of Literary Terms
} 
"End-stopped line is a poetic line that has a pause at the end and it reflects normal speech patterns and is often marked by punctuation..."

“...verse where the sense and meter coincide in a pause at the end of a line..."

—Michelson's Dictionary of English Poetry

-J.A. Cudon's Dictionary of Literary Terms

"Of a line where the sense (grammar) and the meter end together..."

—Shipley's Dictionary of World's Literature

"...the line in a verse which contains the complete sense both in its grammatical structure and semantic form and does not require enjambment or running-on..."

—Rajimwale's Dictionary of Literary Terms

As you can see from the definitions, end-stopping is a phenomenon marking a line in a poem as complete, both grammatically and semantically. Another structural difference between an end-stoped and enjambed line would be the common punctuationat the end of the line; an end-stopped line usually ends with acolon, semicolon or full stop, unlike enjambed lines which have no punctuation mark at their end.

End-stopping is also called rejet in French literature ${ }^{18}$ and the term single-moulded line is sometimes used interchangeably with end-stopped, though seemingly being a subcategory of it which was favorably used by blank verse writers, like Marlowe ${ }^{19}$.

According to Shipley ${ }^{20}$ and Hunley ${ }^{21}$, Alexander Pope, in his heroic couplets, and French poets in their syllabic alexandrines, made a great use of this. End-stopped couplets were characteristic of a great deal of $18^{\text {th }}$ century poetry ${ }^{22}$ and heroic couplet (partial pause at the end of first line; couplet at the end of couplet) ${ }^{23}$. Examples named for this technic are again parts of Keats' Endymion, and parts of Pope's Essays of Man. Take these lines into consideration:

Hope springs eternal in the human breast,

Man never is, but always to be blest.

(Anonymous from Shipley's Dictionary of World Literature)

Or

My mistress' eyes are nothing like the sun;

Coral is far more red than her lips red;

(Shakespeare -sonnet 130)

\section{METHODS AND MATERIALS}

Since the poetic corpus of medieval era is very vast, thus unmanageable and time-consuming, we have restricted our investigation to the works written form1300 AD to $1400 \mathrm{AD}$, specifically the most renowned works of Chaucer, Gower, and Langland. To investigate the two phenomena, enjambment and end-stopping, we have used the non-translated versions of their works as the focus of our work since there may exist some structural differences in the translated ones. However, to show the semantic aspect of these two phenomena, we have used the translated versions to clarify the running-on of sense or vice versa.

For Chaucer, we have chosen General Prologue and The Wife of Bath's tale of his work the Canterbury Talesfrom Norton Anthology of Poetry and the simplified version of it from World's Classics series of Oxford University Press. For Langland, parts of Prologue and Passus VIII of his most known work Pires the Plowman was selected and samples of it were prepared from the B version original text published by Oxford University Press and it's translation by Ben Byram-Wigfield ${ }^{24}$; the B version was chosen as it is noted by both the editor of the original text and the translator to be the most authentic one. For Gower, Part I of both Incipit Liber Primus and Incipit Liber Septimus of his Confessio Amantis or Lover's Confession was used to, the original text of which was taken from John Gower's Complete Works published by Clarendon Press (Oxford) and its simplified version

\footnotetext{
${ }^{18}$ Shipley and J.A. Cudon

${ }^{19}$ Cudon's Dictionary of Literary Terms

${ }^{20}$ Dictionary of World Literature

${ }^{21}$ The Poetry Gymnasium

${ }^{22}$ From the same

${ }^{23}$ William Hint thrall's a Handbook of Literature

${ }^{24}$ Found on: http://www.ancientgroove.co.uk/books/PiersPlowman
} 
translated by Richard Bordie ${ }^{25}$. The parts are intentionally chosen in an alternative way so that a general idea of the whole poem could be elicited. Form the parts mentioned above, the first 100 lines were examined for the use of the two technics.

We havebased our examination on the definition provided by Brink about enjambment; that is we have considered lines, incomplete both syntactically and semantically as enjambed; and the Oxford Dictionary of Literary Terms' definition of endstopping, the vice versa of enjambed lines, complete in terms of both syntax and semantic.

\section{RESULTS AND DISCUSSION}

According to the definition provided by Brink, earlier mentioned in this paper, samples were examined for enjambment and endstopping, the results of which you may find in Table 1.

Table.1: Quantity of enjambed and end-stopped lines traced in the three poems

\begin{tabular}{|c|c|c|c|c|}
\hline \multirow[t]{2}{*}{ Title } & \multicolumn{2}{|c|}{ Part I } & \multicolumn{2}{|c|}{ Part II } \\
\hline & Enjambed lines & End-stopped lines & Enjambed lines & End-stopped lines \\
\hline & \multicolumn{2}{|c|}{ General Prologue } & \multicolumn{2}{|c|}{ The Wife of Bath's tale } \\
\hline \multirow[t]{2}{*}{ Canterbury Tales } & 38 & 62 & 34 & 66 \\
\hline & \multicolumn{2}{|c|}{ Incipit Liber Primus } & \multicolumn{2}{|c|}{ Incipit Liber Septimus } \\
\hline \multirow[t]{2}{*}{ Confessio Amantis } & 25 & 75 & 32 & 68 \\
\hline & \multicolumn{2}{|c|}{ Prologue } & \multicolumn{2}{|c|}{ Passus VIII } \\
\hline Piers the Plowman & 33 & 67 & 24 & 76 \\
\hline
\end{tabular}

As it can be seen in Table 1, in all of the parts chosen to be examined, the quantity of end-stopped lines outdistances the enjambed ones, to a great deal. Amongst the 600 lines examined, 414 are end-stopped, and the remaining ones enjambed. This number accounts for $69 \%$ of the lines. This, evidently, supports our afore-mentioned thesis that the number of enjambed lines would be less than end-stopped ones in Middle-English poetry, as Middle-English poets were, according to Gaylord, who, however, excludes Chaucer as the pioneer of enjambment, more concerned about the lexical complexity of the verse rather than the syntactic complexity. It is well understood that these poets are more inclined to use end-stopping technic and mark an end to their lines. This may be due to the custom of poem composition and the general taste of the readers as end-stopped lines are better and more easily understood. As the time went on to the Elizabethan time, the taste changed and people wanted something more complex and challenging, afar from the simplicity of Old and Middle-English poetry. This actually resulted in the appearance of poets such as Shakespeare, Daniel, Drayton, Sidney, Spenser, Jonson and many others. A text will not be read by the mass until the majority likes it; a shift from simplicity of text into the complexity of the use of enjambment (according to J.A. Cudon, Hunley and many others, the utmost use of enjambment was seen in the Elizabethan era in England), shows how the taste of the readers changed. Comparing these narrative poems to those of Elizabethan era, such as Shakespeare's Venus and Adonis, Marlowe's Hero and Leander, and Drayton's Poly-Olbion, to name a few, the latter ones are more complex in terms of structure, showing an excessive use of enjambment ${ }^{26}$; as Tom C. Hunley in his The Poetry Gymnasium says: "Elizabethan-era poets frequently enjambed their poems; Shakespeare used it more and more in his plays."Therefore, the exceeding number of endstopped in comparison to enjamped lines shows both simplicity in the structure of these poet's poetry and their indifference toward the syntactic and structural complexity which may be imparted through enjambment as one of its main technics.

\section{CONCLUSION}

In this paper, we have examined the existence and quantity two technics called "enjambment" and "end-stopping" in poetry, and the complexity that they, specifically enjambment, can impart on the verse. We based our study on Brink's definition of enjambment, and Oxford Dictionary of Literary Terms' definition of end-stopped lines. We have then examined Chaucer's Canterbury Tales, Gower's Confessio Amantis and Langland's Piers the Plowman. From each of these, 200 lines were alternatively selected from different parts as samples in order that we achieve a general idea about the whole poem. Results have shown that the number of end-stopped lines were far more than enjambed lines, proving the simplicity of these representative

${ }^{25}$ Found on: www.richardbordie.com

${ }^{26}$ The Poetry Gymnasium 
poems of Middle-English literature. It was then concluded that the inclination of these poets to use structural complexities was low and they preferred to keep their message as explicit as possible.

\section{Appendix}

Sample poems:

1. Geoffrey Chaucer's Canterbury Tales

a. General Prologue:

Whan that Aprille, with hise shoures soote,

The droghte of March hath perced to the roote

And bathed every veyne in swich licour,

Of which vertu engendred is the flour;

Whan Zephirus eek with his swete breeth

Inspired hath in every holt and heeth

The tendre croppes, and the yonge sonne

Hath in the Ram his halfe cours yronne,

And smale foweles maken melodye,

That slepen al the nyght with open eye-

So priketh hem Nature in hir corages-

Thanne longen folk to goon on pilgrimages

And palmeres for to seken straunge strondes

To ferne halwes, kowthe in sondry londes;

And specially, from every shires ende

Of Engelond, to Caunturbury they wende,

The hooly blisful martir for the seke

That hem hath holpen, whan that they were seeke.

Bifil that in that seson, on a day,

In Southwerk at the Tabard as I lay,

Redy to wenden on my pilgrymage

To Caunterbury, with ful devout corage,

At nyght were come into that hostelrye

Wel nyne and twenty in a compaignye

Of sondry folk, by aventure yfalle

In felaweshipe, and pilgrimes were they alle,

That toward Caunterbury wolden ryde.

The chambres and the stables weren wyde,

And wel we weren esed atte beste;

And shortly, whan the sonne was to reste,

So hadde I spoken with hem everychon

That I was of hir felaweshipe anon,

And made forward erly for to ryse

To take our wey, ther as I yow devyse.

But nathelees, whil I have tyme and space,

Er that I ferther in this tale pace, 
Me thynketh it acordaunt to resoun

To telle yow al the condicioun

Of ech of hem, so as it semed me,

And whiche they weren, and of what degree,

And eek in what array that they were inne;

And at a knyght than wol I first bigynne.

A knyght ther was, and that a worthy man,

That fro the tyme that he first bigan

To riden out, he loved chivalrie,

Trouthe and honour, fredom and curteisie.

Ful worthy was he in his lordes werre,

And therto hadde he riden, no man ferre,

As wel in Cristendom as in Hethenesse,

And evere honoured for his worthynesse.

At Alisaundre he was, whan it was wonne;

Ful ofte tyme he hadde the bord bigonne

Aboven alle nacions in Pruce;

In Lettow hadde he reysed, and in Ruce,

No cristen man so ofte of his degree.

In Gernade at the seege eek hadde he be Of Algezir, and riden in Belmarye;

At Lyeys was he, and at Satalye,

Whan they were wonne; and in the Grete See

At many a noble arive hadde he be.

At mortal batailles hadde he been fiftene, And foughten for oure feith at Tramyssene In lystes thries, and ay slayn his foo.

This ilke worthy knyght hadde been also

Somtyme with the lord of Palatye

Agayn another hethen in Turkye,

And everemoore he hadde a sovereyn prys.

And though that he were worthy, he was wys,

And of his port as meeke as is a mayde;

He nevere yet no vileynye ne sayde

In al his lyf unto no maner wight;

He was a verray parfit gentil knyght.

But for to tellen yow of his array,

His hors weren goode, but he was nat gay.

Of fustian he wered a gypoun,

Al bismotered with his habergeoun;

For he was late ycome from his viage, 
And wente for to doon his pilgrymage.

With hym ther was his sone, a yong Squier,

A lovyere and a lusty bacheler,

With lokkes crulle, as they were leyd in presse.

Of twenty yeer of age he was, I gesse.

Of his stature he was of evene lengthe,

And wonderly delyvere, and of greet strengthe.

And he hadde been somtyme in chyvachie

In Flaundres, in Artoys, and Pycardie,

And born hym weel, as of so litel space,

In hope to stonden in his lady grace.

Embrouded was he, as it were a meede,

$\mathrm{Al}$ ful of fresshe floures whyte and reede;

Syngynge he was, or floytynge, al the day,

He was as fressh as is the monthe of May.

Short was his gowne, with sleves longe and wyde.

Wel koude he sitte on hors, and faire ryde,

He koude songes make, and wel endite,

Juste, and eek daunce, and weel purtreye and write.

So hoote he lovede, that by nyghtertale

He slepte namoore than dooth a nyghtyngale.

Curteis he was, lowely, and servysable,

And carf biforn his fader at the table.

b. The Wife of Bath's Tale:

In tholde dayes of the Kyng Arthour,

Of which that Britons speken greet honour,

All was this land fulfild of Fayerye.

The elf-queene, with hir joly compaignye,

Daunced ful ofte in many a grene mede;

This was the olde opinion, as I rede.

I speke of manye hundred yeres ago;

But now kan no man se none elves mo,

For now the grete charitee and prayeres

Of lymytours, and othere hooly freres,

That serchen every lond and every streem

As thikke as motes in the sonne-beem,

Blessynge halles, chambres, kichenes, boures,

Citees, burghes, castels, hye toures,

Thropes, bernes, shipnes, dayeryes,

This maketh that ther been no Fayeryes.

For ther as wont to walken was an elf, 
Ther walketh now the lymytour hymself

In undermeles and in morwenynges,

And seyth his matyns and his hooly thynges

As he gooth in his lymytacioun.

Wommen may go saufly up and doun;

In every bussh or under every tree

Ther is noon oother incubus but he, And he ne wol doon hem but dishonour.

And so bifel it that this kyng Arthour Hadde in his hous a lusty bachelor, That on a day cam ridynge fro ryver; And happed that, allone as she was born, He saugh a mayde walkynge hym biforn,

Of whiche mayde anon, maugree hir heed, By verray force he rafte hir maydenhed; For which oppressioun was swich clamour And swich pursute unto the kyng Arthour, That dampned was this knyght for to be deed

By cours of lawe, and sholde han lost his heed, Paraventure, swich was the statut tho,

But that the queene and othere ladyes mo So longe preyeden the kyng of grace, Til he his lyf hym graunted in the place,

And yaf hym to the queene al at hir wille, To chese, wheither she wolde hym save or spille. The queene thanketh the kyng with al hir myght, And after this thus spak she to the knyght, Whan that she saugh hir tyme, upon a day,

"Thou standest yet," quod she, "in swich array That of thy lyf yet hastow no suretee. I grante thee lyf, if thou kanst tellen me What thyng is it that wommen moost desiren. Be war and keep thy nekke-boon from iren,

And if thou kanst nat tellen it anon, Yet shal I yeve thee leve for to gon A twelf-month and a day to seche and leere An answere suffisant in this mateere; And suretee wol I han, er that thou pace,

Thy body for to yelden in this place."

Wo was this knyght, and sorwefully he siketh, But what! he may nat do al as hym liketh; 
And at the laste he chees hym for to wende,

And come agayn right at the yeres ende,

With swich answere as God wolde hym purveye;

And taketh his leve, and wendeth forth his weye.

He seketh every hous and every place,

Where as he hopeth for to fynde grace

To lerne what thyng wommen loven moost;

But he ne koude arryven in no coost

Wher as he myghte fynde in this mateere

Two creatures accordynge in feere.

Somme seyde, wommen loven best richesse,

Somme seyde honour, somme seyde jolynesse,

Somme riche array, somme seyden lust abedde, And oftetyme to be wydwe and wedde.

Somme seyde, that oure hertes been moost esed Whan that we been yflatered and yplesed-

He gooth ful ny the sothe, I wol nat lye,

A man shal wynne us best with flaterye; And with attendance and with bisynesse Been we ylymed, bothe moore and lesse.And somme seyn, how that we loven best For to be free, and do right as us lest,

And that no man repreve us of oure vice, But seye that we be wise, and nothyng nyce. For trewely, ther is noon of us alle, If any wight wol clawe us on the galle, That we nel kike; for he seith us sooth;

Assay, and he shal fynde it that so dooth. For be we never so vicious withinne, We sol been holden wise, and clene of synne. And somme seyn, that greet delit han we For to been holden stable and eke secree,

And in o purpos stedefastly to dwelle, And nat biwerye thyng that men us telle. But that tale is nat worth a rake-stele, Pardee, we wommen konne no thyng hele. Witnesse on Myda-wol ye heere the tale?

Ovyde, amonges othere thynges smale, Seyde, Myda hadde under his longe heres Growynge upon his heed two asses eres, The whiche vice he hydde, as he best myghte, 
Ful subtilly from every mannes sighte;

2. John Gower's Confessio Amantis

a. Incipit Liber Primus:

I may noght strecche up to the hevene

Min hand, ne setten al in evene

This world, which evere is in balance:

It stant noght in my sufficance

So grete thinges to compasse,

Bot I mot lete it overpasse

And treten upon othre thinges.

Forthi the Stile of my writinges

Fro this day forth I thenke change

And speke of thing is noght so strange,

Which every kinde hath upon honde,

And wherupon the world mot stonde,

And hath don sithen it began,

And schal whil ther is any man;

And that is love, of which I mene

To trete, as after schal be sene.

In which ther can noman him reule,

For loves lawe is out of reule,

That of tomoche or of tolite

Welnyh is every man to wyte,

And natheles ther is noman

In al this world so wys, that can

Of love tempre the mesure,

Bot as it falth in aventure:

For wit ne strengthe may noght helpe,

And he which elles wolde him yelpe

Is rathest throwen under fote,

Ther can no wiht therof do bote.

For yet was nevere such covine,

That couthe ordeine a medicine

To thing which god in lawe of kinde

Hath set, for ther may noman finde

The rihte salve of such a Sor.

It hath and schal ben everemor

That love is maister wher he wile,

Ther can no lif make other skile;

For wher as evere him lest to sette,

Ther is no myht which him may lette.

Bot what schal fallen ate laste,

The sothe can no wisdom caste,

Bot as it falleth upon chance;

For if ther evere was balance

Which of fortune stant governed,

I may wel lieve as I am lerned

That love hath that balance on honde, 
Which wol no reson understonde.

For love is blind and may noght se,

Forthi may no certeinete

Be set upon his jugement,

Bot as the whiel aboute went

He yifth his graces undeserved,

And fro that man which hath him served

Fulofte he takth aweye his fees,

As he that pleieth ate Dees,

And therupon what schal befalle

He not, til that the chance falle,

Wher he schal lese or he schal winne.

And thus fulofte men beginne,

That if thei wisten what it mente,

Thei wolde change al here entente.

And forto proven it is so,

I am miselven on of tho,

Which to this Scole am underfonge.

For it is siththe go noght longe,

As forto speke of this matiere,

I may you telle, if ye woll hiere,

A wonder hap which me befell,

That was to me bothe hard and fell,

Touchende of love and his fortune,

The which me liketh to comune

And pleinly forto telle it oute.

To hem that ben lovers aboute

Fro point to point I wol declare

And wryten of my woful care,

Mi wofull day, my wofull chance,

That men mowe take remembrance

Of that thei schall hierafter rede:

For in good feith this wolde I rede,

That every man ensample take

Of wisdom which him is betake,

And that he wot of good aprise

To teche it forth, for such emprise

Is forto preise; and therfore I

Woll wryte and schewe al openly

How love and I togedre mette,

Wherof the world ensample fette

Mai after this, whan I am go,

Of thilke unsely jolif wo,

Whos reule stant out of the weie,

Nou glad and nou gladnesse aweie,

And yet it may noght be withstonde

For oght that men may understonde.

Upon the point that is befalle

Of love, in which that I am falle, 
I thenke telle my matiere:

Now herkne, who that wol it hiere,

Of my fortune how that it ferde.

This enderday, as I forthferde

To walke, as I yow telle may,-

And that was in the Monthe of Maii

b. Incipit Liber Septimus:

I Genius the prest of love,

Mi Sone, as thou hast preid above

That I the Scole schal declare

Of Aristotle and ek the fare

Of Alisandre, hou he was tauht, I am somdel therof destrauht;

For it is noght to the matiere

Of love, why we sitten hiere

To schryve, so as Venus bad.

Bot natheles, for it is glad,

So as thou seist, for thin aprise

To hiere of suche thinges wise,

Wherof thou myht the time lisse,

So as I can, I schal the wisse:

For wisdom is at every throwe

Above alle other thing to knowe

In loves cause and elleswhere.

Forthi, my Sone, unto thin Ere,

Though it be noght in the registre

Of Venus, yit of that Calistre

And Aristotle whylom write

To Alisandre, thou schalt wite.

Bot for the lores ben diverse,

I thenke ferst to the reherce

The nature of Philosophie,

Which Aristotle of his clergie,

Wys and expert in the sciences,

Declareth thilke intelligences,

As of thre pointz in principal.

Wherof the ferste in special

Is Theorique, which is grounded

On him which al the world hath founded,

Which comprehendeth al the lore.

And forto loken overmore,

Next of sciences the seconde

Is Rethorique, whos faconde

Above alle othre is eloquent:

To telle a tale in juggement

So wel can noman speke as he.

The laste science of the thre

It is Practique, whos office 
The vertu tryeth fro the vice,

And techeth upon goode thewes

To fle the compaignie of schrewes,

Which stant in disposicion

Of mannes free eleccion.

Practique enformeth ek the reule,

Hou that a worthi king schal reule

His Realme bothe in werre and pes.

Lo, thus danz Aristotiles

These thre sciences hath divided

And the nature also decided,

Wherof that ech of hem schal serve.

The ferste, which is the conserve

And kepere of the remnant,

As that which is most sufficant

And chief of the Philosophie,

If I therof schal specefie

So as the Philosophre tolde,

Nou herkne, and kep that thou it holde.

Of Theorique principal

The Philosophre in special

The propretees hath determined,

As thilke which is enlumined

Of wisdom and of hih prudence

Above alle othre in his science:

And stant departed upon thre,

The ferste of which in his degre

Is cleped in Philosophie

The science of Theologie,

That other named is Phisique,

The thridde is seid Mathematique.

Theologie is that science

Which unto man yifth evidence

Of thing which is noght bodely,

Wherof men knowe redely

The hihe almyhti Trinite,

Which is o god in unite

Withouten ende and beginnynge

And creatour of alle thinge,

Of hevene, of erthe and ek of helle.

Wherof, as olde bokes telle,

The Philosophre in his resoun

Wrot upon this conclusioun,

And of his wrytinge in a clause

He clepeth god the ferste cause, Which of himself is thilke good,

Withoute whom nothing is good,

Of which that every creature

Hath his beinge and his nature. 
After the beinge of the thinges

Ther ben thre formes of beinges:

Thing which began and ende schal,

That thing is cleped temporal;

Ther is also be other weie

Thing which began and schal noght deie.

As Soules, that ben spiritiel,

Here beinge is perpetuel:

Bot ther is on above the Sonne,

Whos time nevere was begonne,

3. William Langland's Piers the Plowman

a. Prologue:

In a somer sesun, whon softe was the sonn\{.e\},

I schop me into a shroud, as I a scheep wer $\{. e\}$;

In habite as an hermite unholy of werk $\{. e\} s$

Wente I wyde in this world wondr $\{. e\}$ s to her $\{. e\}$;

Bote in a May $\{. e\}$ s morwnynge on Malverne hull $\{. e\} s$

Me bifel a ferly, of fairie, me-thought $\{. e\}$.

I was wery, forwandr $\{. e\} d$, and went $\{. e\}$ me to rest $\{. e\}$

Undur a brod banke bi a bourn $\{. e\} \operatorname{sid}\{. e\}$;

And as I lay and leon $\{. e\}$ de and lok $\{. e\}$ de on the watr $\{. e\} s$,

I slumbr $\{. e\}$ de in a slepynge, hit swy $\{. e\} d$ so muri $\{. e\}$.

Thenne gon I meeten a mervelous sweven,

That I was in a wilderness $\{. e\}$, wuste I never wher $\{. e\}$;

And as I beheold into the est an heigh to the sonn \{.e\},

I sauh a tour on a toft, try\{.e\}lyche i-maket;

A deop dal $\{. e\}$ bineoth $\{. e\}$, a dungun ther-inn $\{. e\}$,

With deop dich and derk and dredful of sight $\{. e\}$.

A feir feld full of folk fond I ther bitwen $\{. e\}$,

Of all $\{. e\}$ maner of men, the mene and the rich $\{. e\}$,

Worchinge and wandringe as the world asketh.

Summ $\{. e\}$ putten hem to the plough, pleiden ful selden $\{. e\}$,

In settynge and in sowyng $\{. e\}$ swonken ful hard \{.e\},

And wonnen that theos wasturs with glotonye distruen.

And summ $\{. e\}$ putten hem to pruid $\{. e\}$, apparaylden hem ther-after,

In cuntenaunce of clothing $\{. e\}$ comen disgisid.

To preyer $\{. e\} s$ and to penaunc $\{. e\}$ putten hem mony $\{. e\}$,

For love of ur Lord liv\{.e\}den ful streit $\{. e\}$,

In hop $\{. e\}$ for to hav $\{. e\}$ hevene-rich $\{. e\}$ bliss $\{. e\}$;

As ancr $\{. e\} s$ and hermyt $\{. e\} s$ that holdeth hem in heor $\{. e\} \operatorname{cell}\{. e\} s$,

Coveyt $\{. e\}$ not in cuntré to cairen about $\{. e\}$,

For non likerous lyflod \{.e\} heor $\{. e\}$ licam to ples $\{. e\}$.

And summ $\{. e\}$ chosen chaffar $\{. e\}$ to cheeven the bettr $\{. e\}$,

As hit semeth to $\operatorname{ur}\{. e\} \operatorname{sight}\{. e\}$ that such $\{. e\}$ men thryveth;

And summ $\{. e\}, \operatorname{murthh}\{. e\}$ s to maken as munstrals cunn $\{. e\}$,

And get $\{. e\}$ gold with her $\{. e\}$ gle, giltles, I trow $\{. e\}$. 
Bote japers and jangelers, Judas children,

Founden hem fantasy $\{. e\} s$ and fool $\{. e\} s$ hem maaden,

And habbeth wit at heor $\{. e\}$ will $\{. e\}$ to worchen yif hem lust $\{. e\}$.

That Poul precheth of hem, I dar not preoven heer $\{. e\}$;

Qui loquitur turpiloquium he is Lucifer $\{. e\}$ s hyn $\{. e\}$.

Bidders and beggers faste aboute eoden,

Til heor bagg $\{. e\} s$ and heore balies weren bretful i-crommet;

Feyneden hem for heor $\{. e\}$ food $\{. e\}$, foughten att $\{. e\}$ al $\{. e\}$;

In glotony $\{. e\}$, God wot, gon heo to bedd $\{. e\}$,

And ryseth up with ribaudy $\{. e\}$ this roberd $\{. e\} s \operatorname{knav}\{. e\}$ s;

Sleep and sleughth $\{. e\}$ suweth hem ever $\{. e\}$.

Pilgrimes and palmers plihten hem togeder $\{. \mathrm{e}\} \mathrm{s}$

For to $\operatorname{sech}\{. e\} \operatorname{Seint} \operatorname{Jam}\{. e\}$ and seint $\{. e\}$ s at $\operatorname{Room}\{. e\}$;

Wenten forth in heor $\{. e\}$ wey with mony wys $\{. e\} \operatorname{tal}\{. e\} s$,

And hedden lev\{.e\} to lyen al heor\{.e\} lyf aftir.

Ermyt $\{. e\} s$ on an hep with hokid $\{. e\} \operatorname{stav}\{. e\} s$,

Wenten to Walsyngham and her\{.e\} wenchis after;

Gret $\{. e\} \operatorname{lobr}\{. e\} s$ and long $\{. e\}$ that loth weor $\{. e\}$ to swynk $\{. e\}$

Clotheden hem in cop $\{$.e $\} \mathrm{s}$ to beo knowen for bretheren;

And summ $\{. e\}$ schopen hem to hermyt $\{. e\}$ s heore es $\{. e\}$ to hav $\{. e\}$.

I fond there frer $\{. e\} s$, all the foure $\operatorname{ordr}\{. e\} \mathrm{s}$,

Prechinge the pepl\{.e\} for profyt of heor $\{. e\}$ womb $\{. e\} s$,

Glosynge the Gospel as hem good liketh,

For covetyse of $\operatorname{cop}\{. e\}$ s construeth hit ill\{.e\};

For monye of this maistr $\{. e\}$ s mowen clothen hem at lyking,

For moneye and heor $\{. e\}$ marchaundi $\{. e\}$ meeten togeder $\{. e\}$;

Sethth\{.e\} Charité hath be chapmon, and cheef to schriven lord $\{. e\} s$,

Mony ferly\{.e\}s han bifall $\{. e\}$ in a few $\{. e\}$ yer $\{. e\} s$.

But Holychirche and heo hold $\{. e\}$ bet togeder\{.e\},

The most $\{. e\}$ mischeef on mold $\{. e\}$ is mountyng up fast $\{. e\}$.

Ther prechede a pardoner, as he a prest wer $\{. e\}$,

And brought forth a bull $\{. e\}$ with bisschop $\{. e\} \mathrm{s} \operatorname{sel}\{. \mathrm{e}\} \mathrm{s}$,

And seid $\{. e\}$ that himself might $\{. e\}$ asoylen hem all $\{. e\}$

Of falsnesse and fastinge and of vouw $\{. e\}$ s i-broken.

The lewed $\{. e\}$ men levide him wel and $\operatorname{lik}\{. e\}$ de his $\operatorname{spech}\{. e\}$,

And comen up knelyng $\{. e\}$ to kissen his bull $\{. e\}$;

He bonch $\{. e\}$ de hem with his brevet and bler $\{$.e $\}$ d heore eiyen,

And raught $\{. e\}$ with his $\operatorname{rag}\{. e\}$ mon $\operatorname{ring}\{. e\} s$ and broch $\{. e\} s$.

Thus ye yiveth our\{.e\} gold glotonis to helpen!

And leveth hit to losels that lecherie haunten.

Weor $\{. e\}$ the bisschop i-blesset and worth bothe his er\{.e\}s,

His sel shulde not be sent to deceyv $\{. e\}$ the pepl\{.e\}.

It is not al bi the bisschop that the boy\{.e\} precheth,

Bote the parisch prest and the pardoner part $\{. e\}$ the selver

That the por\{.e\} peple of the parisch schulde have yif that heo ne weor $\{. e\}$,

Person $\{. e\}$ s and parisch prest $\{. e\}$ s playneth to heor $\{. e\}$ bisschops, 
That heor $\{. e\}$ parisch hath ben por\{.e\} $\operatorname{seth} t h\{. e\}$ the pestilenc $\{. e\} \operatorname{tym}\{. e\}$,

To have a lycence and lev\{.e\} at Londun to dwell $\{. e\}$,

To sing $\{. e\}$ ther for simony $\{. e\}$, for selver is swet $\{. e\}$.

Ther hovide an hundret in houv $\{. e\} \mathrm{s}$ of $\operatorname{selk}\{. e\}$,

Serjauns hit semid $\{. e\}$ to serven att $\{. e\} \operatorname{barr}\{. e\}$

Pleden for pens and pound $\{. e\}$ s the law $\{. e\}$,

Not for love of ur Lord unloseth heor\{.e\} $\operatorname{lipp}\{. e\} s$ on $\{. e\} s$,

Thou mightest beter meten the myst on Malvern $\{. e\}$ hull $\{. e\} s$

Then geten a mom of heor $\{. e\}$ mouth til moneye weor $\{. e\}$ schew $\{. e\} d$ !

I saugh ther bisschops bold $\{. e\}$ and bachilers of divyn $\{. e\}$

Bicoom $\{. e\} \operatorname{clerk}\{. e\}$ s of acount $\{. e\}$ the king for to serven.

Erchedeken $\{. e\}$ s and denis, that dignité haven

To $\operatorname{prech}\{. e\}$ the pepl $\{. e\}$ and por $\{. e\} \operatorname{men}$ to feed $\{. e\}$,

Beon lopen to Londun, bi leve of heor $\{. e\}$ bisschop $\{. e\} s$,

To ben clerk\{.e\}s of the Kyng \{.e\}s Bench\{.e\} the cuntré to schend\{.e\}

Barouns and burgeis and bond $\{$.e $\}$-men also

I saugh in that semblé, as ye schul heren aftur,

Bakers, bochers, and breusters mony $\{. e\}$,

Wollen $\{. e\}$-websteris, and weveris of lynen,

Taillours, tanneris, and tokkeris both $\{. e\}$,

Masons, minours, and mony other craft $\{. e\} s$,

Dykers, and delvers, that don heor $\{. e\} \operatorname{ded}\{. e\} s$ ill $\{. e\}$,

And driveth forth the long\{.e\} day with "Deu vous $\operatorname{sav}\{. e\}, \operatorname{Dam} \operatorname{Emm}\{. e\} ! "$

Cook $\{. e\} s$ and heor $\{. e\} \operatorname{knav}\{. e\} s$ cryen $" H o t\{. e\} \operatorname{pi}\{. e\} s, \operatorname{hot}\{. e\}$ !

"Good $\{. e\}$ gees and grys! Go we dyn $\{. e\}$, go we!"

Taverners to hem told $\{. e\}$ the $\operatorname{sam}\{. e\} \operatorname{tal}\{. e\}$,

With wyn of Osey\{.e\} and win of Gaskoyn \{.e\},

Of the Ryn and of the Rochel, the rost to defy\{.e\},

Al this I saugh slepynge and $\operatorname{sev}\{. e\} \operatorname{sith}\{. e\}$ s $\operatorname{mor}\{. e\}$.

b. Passus 8 :

Thus yrobed in russet I romed aboute

$\mathrm{Al}$ a somer seson for to seke Dowel,

And frayned ful ofte of folk that I mette

If any wight wiste wher Dowel was at inne,

And what man he myghte be of many man I asked.

Was nevere wight as I wente that me wisse kouthe

Where this leode lenged, lasse ne moore -

Til it bifel on a Friday two freres I mette,

Maistres of the Menours, men of grete witte.

I hailsed hem hendely, as I hadde ylerned,

And preide hem, pur churite, er thei passed ferther,

If they knewe any contree or costes [aboute]

Where that Dowel dwelieth - 'Dooth me to witene;

For [ye] be men of this moolde that moost wide walken,

And knowen contrees and courtes and many kynnes places - 
Bothe princes paleises and povere mennes cotes,

And Dowel and Do-yvele, wher thei dwelle bothe.'

'[Marie!]', quod the Menours, ' [amonges us he dwelleth],

And evere hath, as I hope, and evere shal herafter.'

'Contra!' quod I as a clerc, and comsed to disputen,

And seide, 'Soothly, Sepcies in die cadit iustus.

Sevene sithes, seith the Book, synneth the rightfulle,

And whoso synneth,' I seide, ' [certes] dooth yvele, as me thynketh,

And Dowel and Do-yvele mowe noght dwelle togideres.

Ergo he nys noght alwey at hoom amonges yow freres

He is outhemhile elliswhere to wisse the peple.'

'I shal seye thee, my sone,' seide the frere thanne,

'How seven sithes the sadde man synneth on the day.

By a forbisne,' quod the frere, 'I shal thee faire shewe.

'Lat brynge a man in a boot amydde a brode watre

The wynd and the water and the [waggyng of the boot]

Maketh the man many tyme to falle and to stonde.

For stonde he never so stif, he stumbleth if he meve -

Ac yet is he saaf and sound, and so hym bihoveth;

For if he ne arise the rather and raughte to the steere,

The wynd wolde with the water the boot overthrowe,

And thanne were his lif lost thorugh lachesse of hymselve.

'Right thus it fareth,' quod the frere, ' by folk here on erthe.

The water is Iikned to the world, that wanyeth and wexeth;

The goodes of this grounde arn lik the grete wawes

That as wyndes and wedres walweth aboute;

The boot is likned to oure body that brotel is of kynde,

That thorugh the fend and the flessh and the frele worlde

Synneth the sadde man [seven sithes a day].

'Ac dedly synne doth he noght, for Dowel hym kepeth,

And that is charite the champion, chief help ayein synne;

For he strengtheth man to stonde, and steereth mannes soule

That, though thi body bowe as boot dooth in the watre,

Ay is thi soule saaf but thow thiselve wole

Folwe thi flessh and the fend after-

Do a deedly synne and drenche so thiselve.

[1] Encyclopedia Britannica

\section{REFERENCES}

[2] Merriam Webster's Encyclopedia

[3] Le Grand Robert dictionary

[4] Abrams, M. H., A Glossary of Literary Terms, ninth edition, Boston, Wadsworth Cengage Learning, 2009

[5] Norton Anthology of Poetry, $5^{\text {th }}$ edition, New York, W.W. Norton and Company, 2000.

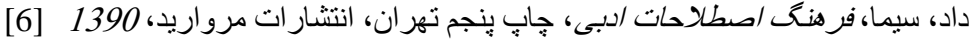

[7] Cudon, J. A., Dictionary of Literary Terms, Penguin Reference, 1996

[8] Rajimwale, Sharad, Dictionary of Literary Terms, KS Paperbacks, 2001

[9] Michelson, M., Dictionary of English Poetry, Sarup and Sons (publishers), 1998

[10] Shaffer, Lawrence, Encyclopedic Dictionary of Literary Criticism, Ivy Publishing House \& Sarup and Sons (publishers), 1996 
[11] Baldick, Chris, Oxford Consize Dictionary of Literary Terms, Oxford University Press, 1989

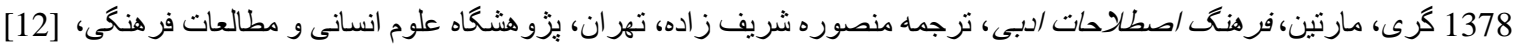

[13] Hint Thrall, William, and Addison Hibbord, A Handbook to Literature, The Odyssey Press, 1999

[14] Oxford Companion to English Literature, London, Oxford University Press, 1987

[15] Chaucer, Geoffrey, The Canterbury Tales, translated by David Wright, Oxford University Press, World's Classics Series, 1985

[16] Byram-Wigfield, Ben, Translation of Langland's Piers the Plowman, online version found on the following link: http://www.ancientgroove.co.uk/books/PiersPlowman

[17] Macaulay, G. C., Complete Works of John Gower, Vol. 2, Oxford University Press, Clarendon Press, first published on 1901

[18] Gaylord, Alan T., the Art of Chaucer's verse, London, Routledge, 2000.

[19] Hori, Masahiro, and Tomoji Tobata, Gadahiro Kumamoto, Hiroyuki Ito, Stylistic Studies of Literature, New York, Peter Lang AG, 2009.

[20]Bordie, Richard, Confessio Amantis rendered into Modern English, online, can be found on the following link: http://www.richardbordie.com

[21] Langland, William, Visions of Piers the Plowman, edited by Walter W. Skeat, London, Oxford University Press, 2001

[22] Shakespeare, William, the Sonnets and Narrative Poems: The Complete Nondramatic Poetry, London, Signet Classic, 2008

[23] Brink, Bernhard ten, The Language and Meter of Chaucer, translated by M. Bentink Smith, New York, Haskel House, 1968

[24] Dupriez, Bernard Marie, a Dictionary of Literary Devices, translated by Albert W. Halsall, Canada, University of Toronto Press, 1991

[25] Meyer, Michael C., Glossary of Literary Terms, Bedford-St. Martin's, 1991

[26] Hunley, Tom C., The Poetry Gymnasium: Proven Exercises to Shape Your Best Verse, 